\title{
A Retailer's Steady Growth Strategy: Should Publix Stay National Or Go Global?
}

Bahaudin G. Mujtaba, (E-mail: Mujtaba@nova.edu), Nova Southeastern University Erica Franklin, (E-mail: efrankl@nova.edu), Nova Southeastern University

\begin{abstract}
Publix Super Markets, Inc. is a Florida-based grocery chain which has over 120,000 employees and annual sales in 2005 of $\$ 20.7$ billion. Presently, Publix serves over one million customers every day and is one of the largest employee-owned companies in the world. Publix is one of Florida's premier supermarkets and has responded to most cultural trends in the grocery market-organic foods; natural foods, health foods, ethnic ingredients, prepared meals, etc. Publix has enjoyed great success in the grocery industry and has expanded in many states. With the advent of globalization affecting almost every industry, the supermarket/food retailing industry has joined the trend. Domestic and international food retailers across the globe have begun to internationalize at a rapid rate and open operations around the world. However, as you will see, the growth of supermarket chains beyond their home countries has been done mostly by European and Asian companies. With the exception of Wal-Mart, few U.S. food retailers have expanded abroad. Currently there are no plans for Publix to expand internationally but this case seeks to examine the possibilities of Publix making a step toward going abroad and highlights the various factors in the global environment that may directly or indirectly affect the company.
\end{abstract}

\section{INTRODUCTION}

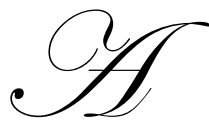

s of August 2006, Publix was operating 833 stores. Publix operates 642 stores in Florida, 164 stores in Georgia, 37 stores in South Carolina, 27 stores in Alabama, and 13 stores in Tennessee. Publix carries items ranging from food products to personal care and household goods. The company also has their own line of private label goods that span the same spectrum. To better cater to their market and expand operations, Publix has also created new concept stores for its different target markets, Greenwise and Publix Sabor. The Greenwise store features organic produce and natural foods; Publix Sabor caters to the large Latin-American population in Central and South Florida and carries food products highly-demanded by these consumer. Publix has also moved into the restaurant business through their equity investment in Crispers, the fresh salad and sandwich meal concept-restaurant. In addition to the restaurant subsidiary, Publix Supermarkets Inc., also owns seven other subsidiaries: 1) Publix Alabama, LLC; 2) PublixDirect, LLC; 3) Publix Asset Management Company; 4) Publix Tennessee, LLC; 5) Real Sub, LLC; 6) Lone Palm Golf Club, LLC; and 7) PTO, LLC. In 2001, Publix began online operations for its consumers for home delivery of groceries. However, its Broward County, FL and surrounding areas pilot programs failed to meet revenue and profit goals; so Publix Direct discontinued operations in August 2003 just short of two years after it was launched. The core of Publix's operations is the belief in doing everything for the customer. The company holds a superior belief that success lies in customer value and employee appreciation. They developed a policy of Customer Intimacy, which means that their guests need an intimate, professional, thorough, consistent, and disciplined method of serving customers that has become a normal way of doing business. See Table 1 for an evolution of Publix's growth since its inception.

\section{COMPANY EARNINGS}

In terms of financial success, in some years, Publix has outperformed the S\&P 500 Index and the customer Peer Group Index with regards to return on investment. The Peer Group includes A\&P, Albertson's, American Stores, Bruno's, Food Lion, Giant Foods, Hannaford Bros., Kroger, Safeway, Smith's Food \& Drug, Weis Markets, and Winn- 
Dixie. Publix announced their 2005 annual results on March $2^{\text {nd }}, 2006$. Their sales for the fiscal year ending December 31, 2005, were $\$ 20.6$ billion. Net earnings for 2005 were $\$ 989.2$ million, compared to $\$ 819.4$ million for 2004 (Publix Announces $4^{\text {th }}$ Quarter, 2006). Dividends for 2006 were $\$ 1.00$ up from 70 cents in 2004 and 40 cents in 2003, which shows that the efforts of Publix's associates to increase earnings via customer value enabled the firm to return an even higher profit to its private stockholders. The 2003 dividend was 40 cents per share, up from 33 cents per share in 2002. Publix CEO Charlie Jenkins Jr. expressed his thanks and appreciation to the firm's workers for their performance that helped increase value to customers and, as a result of which, ensured good financial results for the year.

Table 1 - The Publix Spirit Over The Years

\begin{tabular}{|c|c|}
\hline Year & Accomplishments \\
\hline 1930 & First Publix Super Market opened in Winter Haven, Florida. \\
\hline 1940 & $\begin{array}{l}\text { First store known as the "marble, tile and stucco food palace" built in Winter Haven, featuring such } \\
\text { revolutionary retail concepts as air conditioning, wide aisles, and electric-eye doors. }\end{array}$ \\
\hline 1944 & $\begin{array}{l}\text { Publix bought the 19-store chain of All American Food stores in Lakeland and moved the headquarters to } \\
\text { Lakeland. }\end{array}$ \\
\hline 1950 & $\begin{array}{l}\text { New } 70,000 \text {-square foot grocery warehouse built in Lakeland. Today this warehouse occupies over 2,000,000 } \\
\text { square feet. }\end{array}$ \\
\hline 1957 & Publix Employee Federal Credit Union opened in a Lakeland warehouse. \\
\hline 1959 & Publix opened its first store in Miami and bought seven stores. \\
\hline 1963 & Publix opened the Southeast Coast Headquarters and Distribution Center in North Miami. \\
\hline 1971 & Two stores opened in Jacksonville. \\
\hline 1973 & Publix opened the Bakery Plant and constructed the Produce Distribution Center in Lakeland. \\
\hline 1974 & Publix sales passed \$1 billion annually. Publix opened Distribution Center and Division Office in Jacksonville. \\
\hline 1975 & Publix Employee Stock Ownership Trust (ESOT) started this year. \\
\hline 1980 & $\begin{array}{l}\text { Publix celebrated } 50 \text { years of shopping pleasure. Dairy Processing Plant opened in Lakeland. Checkout } \\
\text { scanning implemented chain-wide. It was during the early 1980's that Publix started being open on Sundays. }\end{array}$ \\
\hline 1984 & $\begin{array}{l}\text { Publix sales passed } \$ 3.23 \text { billion. According to Progressive Grocer, Publix's } 2.36 \% \text { before tax net was the } \\
\text { highest of top ten super market chains, } 21 / 2 \text { times better than Safeway - the industry leader. }\end{array}$ \\
\hline 1986 & Publix opened its first Food and Pharmacy stores in Orlando and Tampa. \\
\hline 1987 & Publix opened its Dairy Processing Plant in Deerfield Beach. \\
\hline 1990 & Publix had 400 stores and 74,000 associates in Florida. \\
\hline 1992 & Publix announced their expansion plans to Georgia and South Carolina. \\
\hline 1993 & $\begin{array}{l}\text { Implemented a company-wide Quality Improvement Process (QIP) and Work Improvement Now (WIN) tools } \\
\text { for fact-based decision-making and employee empowerment. }\end{array}$ \\
\hline 1994 & Sales were $\$ 8.66$ billion. Publix implemented a chain-wide Customer Intimacy program. \\
\hline 1998 & Publix has sales of over $\$ 12$ billion and 120,000 associates. Almost 600 stores in four states. \\
\hline 2000 & Publix was ranked 132 on the Fortune 500. \\
\hline 2001 & Charlie Jenkins Jr. replaced his cousin Howard as CEO of the company. \\
\hline 2002 & Publix began opening stores in Nashville Tennessee. \\
\hline 2003 & Publix makes initial investment in Crispers restaurant chain \\
\hline 2005 & Publix develops ‘concept-stores’-Greenwise \& Publix Sabor ; Sales equal \$20.7 billion \\
\hline 2006 & $\begin{array}{l}\text { Publix stock splits one to five. Publix opens walk-in medical clinics at select grocery locations in Atlanta, } \\
\text { Miami, Orlando and Tampa. Publix further expands with } 6 \text { new store openings between June and August: } \\
\text { Huntsville, AL; Atlanta, GA; Jacksonville, FL(2); Sebastian, FL; Palm City, FL. }\end{array}$ \\
\hline
\end{tabular}

Howard Jenkins, previous CEO of Publix, has been quoted in the past commenting on his company's dedication to customer value, "Publix people have been working hard, preparing for an even grander vision of our future. Earlier in this decade, we committed ourselves to a mission to become the premier quality food retailer in the world. We introduced our own quality improvement process and later adapted a discipline of Customer Intimacy, which is helping us to listen more effectively to our customers. All of these initiatives have engaged the resourcefulness of thousands of associates from every area of our company. Together we are discovering powerful new methods for delivering customer value." 


\section{THE COMPANY}

A key differentiating factor in Publix's success formula can be attributed to the philosophy of its founder, Mr. George W. Jenkins who stated that “... some companies are founded on policy. This is wrong. Philosophy, the things you believe in, is more important. Philosophy does not change frequently ... and is never compromised ... we attempt to adapt a philosophy in such a way as to allow ordinary people to achieve the extraordinary ... to reach higher... to look upon average with disdain." The philosophy of caring for people has been embedded in Publix's corporate culture throughout its stores. Publix associates understand that they are not just in the grocery business but also in the people business. Therefore, taking care of associates, customers, suppliers, and community members is important to Publix people and the communities which they serve. Publix's Mission Statement very clearly states that Publix is passionately focused on customer value. Publix is committed to satisfying the needs of their customers as individuals better than their competition. Also, research shows that the majority of supermarket shoppers shop and visit supermarkets on a weekly basis. So, building a relationship with customers is a necessity as opposed to a luxury in order to stay aware of their needs and expectation. Publix associates are encouraged to interact with their customers on an hourly basis. Publix associates constantly attempt to keep their fingers on the pulse of the customer in order to get immediate and local feedback. One of the District Managers in the Central Florida region used to encourage, and in some cases require, his department managers to learn at least two customers' names, every day through face-to-face introduction and interaction. This is important because Publix employees serve their own communities and through this face-to-face interaction they can better determine customers' needs, wants, and desires faster than any research firm could ever do.

\section{KEY SUCCESS FACTORS}

At Publix, everything they do revolves around pleasing the customer; this is why they have enjoyed the kind of success they have had since the 1930's. Bill Fauerbach, Vice President of the Miami Division, said "only we can give our customers a reason to shop elsewhere." The President of Publix, Ed Crenshaw, during his first year in the office introduced four success drivers for the company. The four drivers are: knowing the business, knowing the product, knowing the customer, and continuously training people. As a result, every department implemented different means of doing a better job with these four success drivers. A philosophy of employee appreciation has been embedded in the culture of the organization; so when the upper echelons visit retail stores, especially during appreciation week, they make it a point to personally see and thank every associate. One obstacle Publix is faced with is strong competition in the supermarket industry. For example, Wal-Mart, now the \#1 retail grocer in the world, is opening major supercenters throughout Florida. However, Publix is not willing to concede their customers to the competition. As long as they take care of their customers better than anyone else, they will do well. The new generation of Publix leaders understands that complacency is their number one enemy; therefore they continue to focus and improve on factors which have made them successful in the past. They further understand that delivering superior customer value is a race without a finish line in today's fast-paced world. Therefore, they never lose sight of caring for people, delivering quality products and service, and excellence in everything they do. They understand that people need recognition and sincere thanks for their hard work and commitment to the company.

Publix has invested heavily in developing an internal professional development curriculum to develop associates' skills and help them assume greater responsibility and leadership roles at Publix. Most employees begin working for Publix at a young age and tend to stay there after college. While a college education is very important for leadership and management positions, Publix provides many continuous development opportunities and on-the-job training for their associates. The philosophy of Publix is not just to satisfy and delight customers one time; customers must be satisfied, delighted, and excited every time they visit or shop at their store. Publix associates are taught that customers are their most valued assets whom must be welcomed, cherished, and appreciated.

Publix associates understand that if they cannot satisfy customer's requirements and meet their demands, the customer will cease to do business with them and may shop with other retailers. They remember that if they, as Publix associates, don't offer a great shopping experience for their customers then someone else will. Therefore, besides discussing many other valuable concepts, all retail associates are taught the 10-Foot and 10-Second Rules to help them quickly acknowledge customers. The 10-Foot rule states that one must acknowledge all customers that are within ten feet 
of one's surroundings and the 10-Second rule states that these customers must be acknowledged within ten seconds of entering into the service counter area or the 10-Foot zone. Research in the supermarket industry indicates the factors that affect customer loyalty:

- $\quad$ The largest percentage of customers (68\%) leave if they perceive an attitude of indifference.

- $\quad$ Some customers (14\%) leave because they feel they can find better quality products and services elsewhere.

- $\quad$ Customers (9\%) shop elsewhere because they think your prices are higher than your competitors.

- A few of the customers (5\%) become friends with people who work for a competitor and take their business there.

- $\quad$ Some customers (3\%) leave because they move to a different area.

Publix Associates are also encouraged to use their daily observations, customer feedback, survey evaluation, and other data to improve their jobs, better serve their customers, and make Publix a better place "where shopping is a pleasure.

Publix teaches the principle of "deliver plus 1\%" which states that you must consistently meet your customers' shopping needs and then exceed their expectations by improving your service one percent. They believe in positively surprising the customer by over-delivering on what customers value. This principle further states that when you make a promise to a customer, you must be consistent and deliver all the time. It means before exceeding your customers' expectations, make sure you are satisfactorily meeting their needs. And if you promise any extra services, make sure you deliver as promised.

Finally, Publix rewards top-notch service by implementing an awards program which shows associates how much management values their efforts to provide delightful service to customers. Delightful Service Awards are given for customer service that is over and above the minimum standards listed on the Observation Sheet for the area. Associates are expected to provide great customer service as part of the job requirement. The awards are given to associates who make the extra effort to delight customers who shop at Publix. To receive a Delightful Service Award associates must provide delightful service to a customer in a way that is formally recognized by either the customer, by a "mystery shopper" who is purposely appointed by district management, or by a member of the store management team. Associates are trained and encouraged to set personal goals for themselves with regards to better serving customers and exceeding their expectations. They are asked to find out what they can do to increase and improve their personal commitment to customer intimacy. They are encouraged and rewarded for setting goals to increase their awareness of customers as well as customers' wants and needs.

It is through these types of programs and committed people that Publix is able to offer its employees an environment "where working is a pleasure" and its customers an environment "where shopping is a pleasure." Publix associates' success with customers originates from their belief that no sale is final or complete until the meal is eaten and fully enjoyed. Then, they have made a positive and lasting impression. Publix's guarantee, which every associate is aware of, reads that "we will never, knowingly disappoint you. If for any reason your purchase does not give you complete satisfaction, the full purchase price will be cheerfully refunded immediately upon request." These are not just words to live by but they are moral imperatives for retailers which have made Publix the successful and innovative giant it is today.

According to Howard Jenkins, member of the Publix board and retired CEO, "growth is the end result of a simple equation. As each of us continues to please our customers, more customers will look to Publix for their shopping needs. We must never lose sight of exactly what those needs are." Keeping their sight on the changing needs of their customers and effectively filling those needs have paid big dividends for Publix's consistent growth and achievement over the years. As a result of the its continued efforts to grow through providing superior customer service and developing and retaining content employees, Publix was once again announced in 2005 a "100 Best Company to Work for" by Fortune magazine. Publix also received its $13^{\text {th }}$ award by Fortune Magazine as a "Most Admired Company."

\section{CURRENT TRENDS IN THE GLOBAL GROCERY INDUSTRY}

As the business world becomes smaller and firms look to expand their reach globally, managers are faced with the task of developing and implementing plans to make the next step to take their firm into the international arena. As 
companies in other industries such as electronics, clothing, and food service have taken their companies abroad, a new trend has begun to emerge within the last decade-grocery chains and supermarkets expanding their companies internationally. The company leading this trend is Wal-Mart which has expanded mostly to Europe and Latin America. However, this trend has been limited to foreign supermarkets expanding into the U.S. market such as Aldi, Tesco, and Famima. American grocery stores have not been very prevalent in the expansion of the industry globally. Tesco and Famima are looking to bring smaller scale grocery retail stores to the U.S. mostly concentrated on the West Coast in California. Famima, the Japanese grocer will offer Chinese and Japanese items which would be sure to please ethnic food seekers. There are a variety of reasons why some U.S. firms have been prompted to expand abroad. The main reason is because of competition in the form of consolidations of grocers. There are a variety of methods firms in the grocery industry use to reach the global market, the most popular being via acquisitions of smaller stores in the host nation. WalMart and IGA have both expanded their global reach through acquisitions. Tesco has expanded their company through the use of joint ventures, acquisitions, stand-alone operations and start-up concepts.

Within the grocery industry, traditional grocers are beginning to stock items that normally do not dot the landscape of a grocery store such as non-food items and traditional retailers of non-food items are starting to sell food products. U.S. Grocery stores and supermarkets thinking of expanding abroad also have to contend with the food retailers in the host nations of both local and foreign firms. For example, hypermarkets are well known throughout Europe and Africa and sell lots of goods ranging from home improvement products to frozen foods; a small U.S. supermarket may have trouble competing with this type of store in an overseas market. Also Wal-Mart has introduced their concept grocery "Neighborhood Center" stores in the U.S. which sell only food products; their strategy abroad involves the large supermarkets, which compete with the local hypermarkets. So not only does a small U.S. grocer have to compete with a local firm, it must compete with other foreign, mainly American firms as well. The rapid growth and development of "supercenters" as evidenced by Wal-mart's grocery industry ascendancy is testament to the viability of hybrid formats (i.e., grocery and general merchandise). Supercenters' sales exceeded $\$ 100$ billion in 2000 (half of which was accounted for by the grocery side of the store). In another example, domestically, Wal-Mart has begun to add new organic food products to its shelves to attract more upscale buyers that would normally attend specialty organic markets or upscale supermarkets. In addition, the legendary furniture producer Ikea has recently decided to expand it specialty-foods segment and will begin selling the items in its stores. The firm has always sold food products and even operates a few restaurants. Retailers also are starting to develop new concept stores which bear the name and likeness of the parent store but cater to a particular ethnic group or food trend. Publix has their two chains, one Latin-oriented and the other organicoriented. Wal-Mart has also developed and expanded their "Neighborhood Market" limited grocer concept.

Over 20,000 new items are hitting the market every year and understanding the value of each product to each customer is no easy task. Therefore, the value of understanding, anticipating, and determining consumer preference cannot be overestimated. Changing effectively is a matter of keeping up with the demands of consumers, offering more value for the customer's dollar, being competitive, and creating raving fans. For example, Publix offers readymade meals which are a growing trend abroad, especially in Asia. Other countries view American brands as a welcome addition to their market place. For example, Japan is a large importer of foreign food supplies and a report out of Sweden recently found Japan as a viable market for foreign investment in food products and supplies.

Food safety is becoming a major issue in the grocery industry. According to a Better Homes and Gardens panel study, only $20 \%$ of the panelists were very confident that the food they buy is safe to eat. Global activist group Greenpeace, has joined two other coalitions-True Food Now and GE-Free Markets-which are trying to convince two supermarket operators in California to stop using genetically engineered ingredients in their private label food lines. According to NBC Dateline investigation, seven of the nation's largest grocery store chains, operating more than 7000 stores in nearly every state, admitted to re-dating meats and fish after they had reached their original "sell-by" date. In the food retailing industry, leaders are paying more attention to ensuring that food products are safe and produced in a clean environment. According to the corporate quality assurance lab coordinator at Publix, their associates are constantly looking at all the risk factors associated with food quality, as well as food safety, while attempting to eliminate them. Firms in any industry operating abroad and at home must also be aware of health risks. The ever publicized, bird-flu, can affect how companies conduct operations. In one move, Publix announced that in case of a bird-flu epidemic in America, it would think about providing curbside delivery of goods to customers. In light of the health risks present to retailers and 
their food supplies, supermarkets must also craft procurement strategies to ensure the products selected to be sold in their stores are free from exposure to such elements prior to being stocked on the companies' shelves. Natural disasters also play a role in food safety as well. When a natural disaster strikes, cities and neighborhoods are often left without electricity and as a result, food establishments are not able to store their perishable items because of the risk of spoilage and making customers sick. To counter this problem, Publix has prepared all of its South Florida stores for hurricane disasters by installing generators in these stores as part of its "Business Recovery Program." This move is seen as a way for the company to remain open during the aftermath of a storm and continue to serve their customers by hopefully reducing lost perishables inventory and helping to ensure that spoiled and tainted food products are not sold to their customers.

Today's customers are increasingly more concerned and vocal about the quality and nutrition of the food they purchase. According to research, 70 percent of women and 54 percent of men say they consider nutrition to be an important factor in their consideration of food purchases. Once a niche category, organic foods are becoming increasingly mainstream as small, regional organic food-producing companies have been acquired by major manufacturers. Today's nutrition-conscious supermarket shoppers are checking labels as never before. The Food and Drug Administration is requiring that trans fat (trans fats are found in foods ranging from partially hydrogenated oils to fried foods, cookies, pastries, dairy products and meats) content appear on all food labels as of January 1, 2006. Finally, some manufacturers are considering the idea of offering "functional foods" which are fortified with a growing number of popular herbs, vitamins, hormones and other healthy additives.

The days of preparing complete meals at home are becoming a distant memory for most working people living in the United States and other developed nations. Today's time poor shoppers are opting for prepared foods such as precut produce, cooked dinners, and prepared takeout foods. Also, 77.4 percent of the respondents purchase prepared foods to eat at home and 49 percent of those who eat at home said they do so because they are more careful about what they eat. It has been said that over 40 percent of all consumer spending on food is for meals that are eaten away from their homes.

\section{EXTERNAL ENVIRONMENTAL FACTORS AFFECTING GLOBAL EXPANSION}

Economic. The economy of the country affects companies if they decide to expand abroad and how they operate. The countries' monetary and economic policies could be discouraging to international investment such as currency controls; unstable exchange rates; high external debt, etc. A retail establishment might be affected by unstable currencies which could leave some customers unable to buy the companies' products and could hamper repatriation of profits back home. The type of economy a country operates under can also have an impact on foreign firms. For example, command, communist, socialist or market-oriented economies also pose different challenges to the multinational firm, and policies of these various economies will in effect determine companies' direction.

Socio-cultural. Elements in the foreign socio-cultural environment will affect decisions to locate abroad. There are various cultural norms that influence consumer behavior, company policies, marketing and product selection such as religion, ethnic norms, etc. The firm must look at new social and cultural trends in the global and country-specific environment and how they affect the market. Some social trends that have emerged in the food industry are healthy foods, organic and natural foods and gourmet take-out. Supermarkets wishing to expand abroad also must take note of regional and country preferences of the consumers in the host nation. What is normally for sale in the home market may be significantly different in the host nation; even more so than the differences in regional areas of the home country. Change is constant and ubiquitous throughout the supermarket industry because customers are becoming more knowledgeable and demanding. In today's market-based economy, customers want a variety of ethnic foods that are made with quality ingredients and represent their culture; therefore quality service must be aligned accordingly with the best prices in order to deliver superior value.

Political/Legal. One of the biggest factors affecting expansion abroad is the level of political risk of a country and its legal environment. The level of political risk involved and its resultant effect on foreign firms are often taken into consideration before a company decides to locate in a foreign market. A new government may expropriate or nationalize 
foreign owned property or all of the companies in a particular industry often with detrimental results to the foreign firm. Also governments sometimes pose through their legal system investment restrictions on foreign firms seeking FDI in their countries. This ranges from disallowing $100 \%$ ownership by foreign firms in the host country; mandatory joint venture or strategic alliance agreements; and even restrictions on the building of manufacturing or distribution facilities in the new country.

Demographic. This particular factor in the external environment relates to "who will your customers be?" Will the same demographic segment targeted by the firm in its home country be present in the host nation, such as income, gender, age, education? Are these consumers accessible? Is there a need or want for the firm's particular products? For example, will a traditional supermarket with middle class consumers at home have a large demographic base in a village where poorer customers buy produce from open-air markets? How will the characteristics of the intended target group affect operating strategy? All of the questions must be answered and will directly affect the strategy that a company will take when expanding abroad and even will affect the country of choice for the firm.

Technological. The firm needs to look at new trends in the industry or related industries that will have an effect on their expansion and operations at home and abroad. There is in fact rapid technological innovation in the food-retail industry that companies are starting to take notice of and adopt. Technology which allows customers to be their own cashiers and checkout their own groceries have been around for many years. However, it is only recently that some food retailers are toying with its implementation as a strategic tool to enhance their competitive position and offer better service to the time-impoverished customer. This is because self-checkout technology, which allows shoppers to scan their own items, offers savings to both the shopper and the retailer along with an added convenience. Self-checkouts can serve only a segment of the market which wants to scan their own groceries and have a debit card to pay for their groceries. Check-out efficiency has also been improved by widespread use of debit and credit card payment systems.

\section{CONCLUDING REMARK}

Publix's history shows that they bought seven Grand Union stores in Miami in 1959 and 19 All American stores in 1945 to expand their market share in the Florida market. According to Publix leaders, currently there are no specific plans for mergers or acquisitions. However, they are not against the idea of acquiring another company that fits Publix's culture and philosophy. An executive commented that "If the right opportunity came up we could acquire another company...we may or may not find another company we like...we believe in internal growth, building our own stores." The supermarket industry is becoming increasingly concentrated as large regional chains such as, Wal-Mart, Kroger, Safeway, and Albertson's dominate their markets Publix's current strategy is to steadily grow from within and expand the Publix culture throughout its stores across different states in the United States. If they choose not to go abroad, they better be fully prepared to compete with global firms that will be planning to invade their market in the coming decades. One must ponder on a strategy of Publix going abroad to gain new market share and to gain the relevant experience to compete with global competitors. Or, Publix can simply prepare to protect its territories from foreign retailers that will be competing with them in the United States. What should Publix executives do and how should be they proceed if they are to maximize the value of their stockholders in the long-term?

\section{DISCUSSION QUESTIONS}

- Is Publix ready to go abroad? Defend your statement selection as thoroughly as possible.

- $\quad$ Do Publix managers and employees have the experience to compete in global markets? Discuss.

- What route if any should Publix take to expand abroad? (Think about joint-venture, strategic alliance, licensing, manufacturing, greenfield, etc.)

- If international expansion is not feasible at this time, develop some alternative solutions to Publix growing successfully amid global competitors.

- $\quad$ Beyond product selection, what other aspects of Publix's operations may be affected by going abroad?

- What other factors in the firm's external environment may affect international expansion for Publix?

- Is it better for Publix to go abroad and compete in new markets or simply prepare to compete with global retailers that will be coming into the neighborhood? 


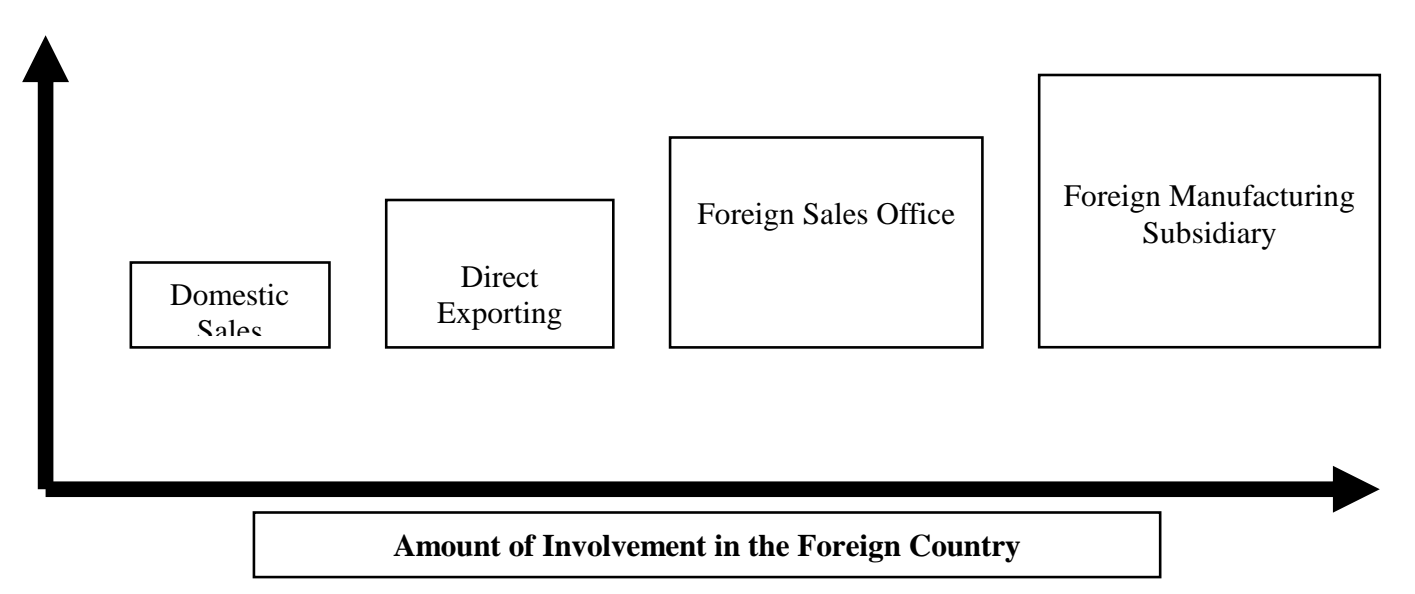

Exhibit 2 - Consolidated Earnings

Publix Super Markets, Inc.

Consolidated Statements of Earnings

Years ended December 31, 2005, December 25, 2004 and December 27, 2003

\begin{tabular}{|c|c|c|c|}
\hline & 2005 & 2004 & 2003 \\
\hline & \multicolumn{3}{|c|}{ (Amounts are in thousands, except share outstanding and per share amounts) } \\
\hline \multicolumn{4}{|c|}{$\mathrm{C}^{2}$} \\
\hline Sales\$ & $20,589,130$ & $18,554,486$ & $16,760,749$ \\
\hline Other operating income & $\underline{155,681}$ & $\underline{131,885}$ & $\underline{126,120}$ \\
\hline Total revenues & $\underline{20,744,811}$ & $\underline{18,686,371}$ & $\underline{16,886,869}$ \\
\hline \multicolumn{4}{|l|}{ Costs and expenses: } \\
\hline Cost of merchandise sold & $15,059,680$ & $13,577,740$ & $12,275,132$ \\
\hline Operating and administrative expenses & $\underline{4,231,402}$ & $\underline{3,869,791}$ & $\underline{3,613,759}$ \\
\hline Total costs and expenses & $\underline{19,291,082}$ & $\underline{17,447,531}$ & $\underline{15,888,891}$ \\
\hline Operating profit & $1,453,729$ & $\underline{1,238,840}$ & $\underline{997,978}$ \\
\hline Investment income, net & 74,293 & 35,311 & 21,926 \\
\hline Other income, net & $\underline{22,716}$ & $\underline{20,860}$ & $\underline{27,185}$ \\
\hline Earnings before income tax expense & $1,550,738$ & $1,295,011$ & $1,047,089$ \\
\hline Income tax expense & $\underline{561,582}$ & 475,628 & $\underline{386,156}$ \\
\hline Net earnings & $\$ \underline{\underline{989,156}}$ & $\underline{\underline{819,383}}$ & $\underline{\underline{660,933}}$ \\
\hline $\begin{array}{l}\text { Weighted average number of } \\
\text { common shares outstanding }\end{array}$ & $\underline{172,039,137}$ & $\underline{\underline{176,775,733}}$ & $\underline{\underline{184,112,742}}$ \\
\hline $\begin{array}{l}\text { Basic and diluted earnings per common share } \\
\text { based on weighted average shares outstanding }\end{array}$ & $\$ 5.75$ & $\underline{\underline{4.64}}$ & $\underline{\underline{3.59}}$ \\
\hline
\end{tabular}


Exhibit 3- Consolidated Comprehensive Earnings

Publix Super Markets, Inc.

Consolidated Statements of Comprehensive Earnings

Years ended December 31, 2005, December 25, 2004 and December 27, 2003

\begin{tabular}{|c|c|c|c|}
\hline & 2005 & 2004 & 2003 \\
\hline & \multicolumn{3}{|c|}{ (Amounts are in thousands) } \\
\hline Net earnings & $\$ 989,156$ & 819,383 & 660,933 \\
\hline \multicolumn{4}{|l|}{ Other comprehensive earnings (losses) } \\
\hline $\begin{array}{l}\text { Unrealized (loss) gain on investment securities available } \\
\text { for-sale, net of tax effect of }(\$ 8,484), \$ 419 \text { and } \$ 3,174 \\
\text { in } 2005,2004 \text { and } 2003 \text {, respectively }\end{array}$ & $(13,510)$ & 668 & 5,055 \\
\hline $\begin{array}{l}\text { Reclassification adjustment for net realized gain on } \\
\text { investment securities available-for-sale, net of tax } \\
\text { effect of }(\$ 1,692),(\$ 1,348) \text { and }(\$ 800) \text { in } 2005 \text {, } \\
2004 \text { and } 2003 \text {, respectively }\end{array}$ & $\underline{(2,695)}$ & $\underline{(2,147)}$ & $\underline{(1,274)}$ \\
\hline Comprehensive earnings & $\$ 972,951$ & $\underline{817,904}$ & $\underline{664,714}$ \\
\hline
\end{tabular}

\section{REFERENCES}

1. Appleson, G. (2006, August 14). Grocery chains blur retailing lines as they bottle Wal-Mart. Knight Ridder Tribune, P. 1

2. Awbi, A. (2006, June 16 Tesco Shifts Focus as foreign business booms. Food \& Drink Europe.com. Retrieved August 21, 2006 from http://www.foodanddrinkeurope.com/news/ng.asp?id=68453.

3. Klintenberg, H. (2003). Japanese Food Market Consumer Market Characteristics, and the foreign entry situation from a Swedish Perspective. Gotenborg, Dept. of Human and Economic Geography. Retrieved August 21, 2006 from http://www.handels.gu.se/epc/archive00003058.

4. Ikea to move into specialty grocery market. (2005, July 11). Food \& Drink Europe.com Retrieved August 24, 2006 from http://www.foodanddrinkeurope.com/news/printNewsBis.asp?id=61218

5. Jackson, J. (2006, April 6). Experts discuss bird-flue response: Publix plan for curbside delivery is an example of how business for the worst. Knight Ridder Business Tribune. Retrieved August 21, 2006 from ProQuest.

6. Mujtaba, B. G. (April 2007). Cross cultural management and negotiation practices. ILEAD Academy Publications; Florida, United States. ISBN: 978-0-9774211-2-1. Website: Ileadacademy.com.

7. Mujtaba, G. B. \& Johnson, W., (2004). Publix Super Markets Inc.: Achieving Customer Intimacy. Case 15; pages 375-392. In William Johnson and Art Weinstein's book entitled Superior Customer Value in New Economy. Second Edition. CRC Press.

8. Orgel, D. (2002, June 17). U.S. Supermarket Operators need a foreign policy. Supermarket News. Retrieved August 21, 2006 from ProQuest Database.

9. Pint Sized Imports. Progressive Grocer (2006, May 15). 8, p. 18. Retrieved August 21, 2006 rom ProQuest Database.

10. Publix. (2006, March 2). Publix Announces 4th Quarter and Annual Results for 2005. Retrieved August 21, 2006 from www.publix.com.

11. Publix. (2006, April 13). Publix Announces Annual Dividend. Retrieved August 21, 2006 from www.publix.com.

12. Publix. (2006). Publix website visited on August 212006 at http://www.publix.com 
13. Publix plans natural prototypes. (2005, May 13). South Florida Business Journal. Retrieved August 21, 2006 from http://www.bizjournals.com/southflorida/stories/2005/05/09/daily52.html.

14. Grocer to add flavor with Hispanic themed stores. (2005, March 7). South Florida Business Journal. Retrieved August 21, 2006 from http://www.bizjournals.com/southflorida/stories/2005/03/07/daily5.html.

15. Ideal Media, LLC. (2006). Restaurant Business: Street smarts for the entrepreneur. Retrieved August 21, 2006 from

http://www.restaurantbiz.com/index.php?option=com content\&task=view\&id=13355\&Itemid=93.

16. Publix. (2006). Publix Super Markets Inc. Annual Report to Stockholders: The Character of Publix.

17. Publix (2006, February 6). Publix and the Little Clinic to open walk-in medical clinics. Retrieved September 16, 2006 from www.publix.com

\section{NOTES}

